\title{
Melalui Penggunaan Alat Bantu (Matras) Dapat Meningkatkan Motivasi Belajar Pada Siswa Kelas VIII SMP Negeri 3 Sampoiniet Dalam Materi Senam Lantai
}

\author{
T. Safran, S.Pd \\ SMP Negeri 3 Sampoiniet
}

\begin{abstract}
Abstrak
Kegiatan ini merupakan Penelitian Tindakan Kelas (PTK). Penelitian dilaksanakan dalam tiga siklus, tiap siklus terdiri atas perencanaan, pelaksanaan tindakan, observasi, dan refleksi. Subyek penelitian adalah siswa kelas VIII SD Negeri 3 Sampoiniet yang berjumlah 18 siswa. Sumber data berasal dari guru dan siswa. Teknik pengumpulan data adalah dengan observasi, wawancara, dan dokumentasi atau Arsip. Validitas data menggunakan teknik triangulasi metode. Analisis data menggunakan teknik analisis statistik deskriptif komparatif dan analisis kritis. Hasil penelitian tindakan kelas ini adalah: (1) Pelaksanaan penggunaan metode demonstrasi dapat meningkatkan prestasi dalam latihan senam lantai untuk mapel Penjaskes; (2) Kualitas pembelajaran mapel penjaskes meningkat dengan penerapan metode demonstrasi, dan menunjukkan bahwa melalui penggunaan alat bantu yaitu berupa ring target dapat meningkatkan hasil latihan senam lantai siswa dari pratindakan ke siklus I, dan ke siklus II. Proses pembelajaran pada pratindakan belum menggunakan alat bantu ini sehingga hasil belajar siswa rendah. Peningkatan terjadi pada siklus I. Hasil belajar siswa meningkat walaupun belum optimal. Pelaksanaan siklus II menyebabkan hasil belajar dalam latihan senam lantai siswa terjadi peningkatan menjadi lebih baik sehingga bisa mendukung suatu pembelajaran yang berkualitas. Simpulan penelitian ini adalah melalui penggunaan alat bantu dapat meningkatkan motivasi belajar dalan materi senam lantai pada siswa Kelas VIII SMP Negeri 3 Sampoiniet Kecamatan Sampoiniet Kabupaten Aceh Jaya Tahun Ajaran 2018/2019.
\end{abstract}

\section{Kata kunci: Metode Demonstrasi, Alat bantu (Matras), Senam Lantai}

\section{PENDAHULUAN}

Pendidikan jasmani pada dasarnya merupakan bagian integral dari sistem pendidikan secara keseluruhan yang bertujuan untuk mengembangkan aspek kesehatan. Pendidikan jasmani merupakan alat untuk mencapai pendidikan jasmani dan olah raga di sekolah sebelum mendapatkan format yang tepat, karena selalu menyesuaikan perubahan kurikulum. Pada kurikulum KBK (Kurikulum Bebasis Kompetensi) diharapkan dapat menggali potensi yang ada untuk dikembangkan, belum bisa dilihat hasilnya dari kurikulum KBK. Ada bentuk kurikulum baru yang disebut K-13 (Kurikulum 2013) yang sekarang sedang dilaksanakan.

Pembelajaran di SMP Negeri 3 Sampoiniet siswa tersebut mengalami kesulitan dalam melakukan tehnik senam lantai. Sebagian besar siswa baru menguasai cara bermain. Mereka belum mampu melakukan gerakan secara keseluruhan terbukti dari hasil evaluasi, dari siswa yang berjumlah 18 anak yang terdiri dari 2 siswa laki-laki dan 16 siswa perempuan, baru 9 siswa (50\%) yang dapat melakukan senam lantai dasar dan sisanya masih 9 siswa (50\%) yang masih belum menguasai latihan senam lantai.

Model pembelajaran dengan pendekatan alat bantu dirancang dengan teliti agar bisa mengembangkan belajar siswa dan dilakukan dengan baik dan dapat dipelajari 
langkah demi langkah. Alat bantu ini aman digunakan dalam pelaksanaan pembelajaran diharapkan membuat siswa lebih mudah menerima materi ajar, dan dapat mengubah suasana menjadi lebih rileks dan menyenangkan bahkan siswa saling berlomba memakai dan melewati alat bantu tersebut. Hal ini akan membantu meningkatkan motivasi siswa terhadap materi Senam lantai.

\section{Tujuan Penelitian}

Penelitian ini bertujuan untuk meningkatkan motivasi belajar tentang senam lantai melalui penggunaan alat bantu pada siswa kelas VIII SMP Negeri 3 Sampoiniet Tahun Ajaran 2018/2019.

\section{TINJAUAN PUSTAKA}

\section{Pengertian Metode Demonstrasi}

Menurut Kamus Besar Bahasa Indonesia (1995: 195) definisi demonstrasi adalah peragaan atau pertunjukan tentang cara melakukan atau mengerjakan sesuatu. Dari pengertian di atas, dapat diartikan bahwa demonstrasi merupakan perbuatan yang langsung bisa dilihat, dirasakan, dan dinikmati secara langsung.

Jika dikaitkan dengan proses pembelajaran, menurut Roestiyah (2001: 83) metode demonstrasi adalah cara mengajar dimana seorang guru atau tim guru menunjukkan, memperlihatkan sesuatu proses, sehingga siswa dalam kelas dapat melihat, mengamati,, mendengar, mungkin meraba-raba dan merasakan proses yang ditunjukkan oleh guru tersebut. Penerapan metode demonstrasi dalam proses pembelajaran akan memudahkan siswa dalam menerima pelajaran. Proses penerimaan siswa terhadap pelajaran akan lebih berkesan secara mendalam, karena siswa dapat melihat secara langsung sehingga akan menumbuhkan persepsi yang mendekati kebenaran serta mebentuk pengertian secara baik dan sempurna.

\section{Penggunaan Media Pembelajaran}

Penggunaan media pembelajaran dalam proses belajar mengajar pada siswa digunakan pada situasi sebagai berukut :

a. Saat suasana siswa lagi bingung dalam memahami proses pembelajaran ini juga salah satu akibat dari kebosanan yang timbul oleh materi guru yang sifatnya menonton tanpa selingan berupa humor yang menyenangkan.

b. Pada waktu pembelajaran dibagian kegiatan inti agar siswa dapat mengenal langsung tentang materi pembelajaran yang mungkin kurang dipahami siswa, dalam situasi seperti ini guru harus berusaha dan bijaksana menampilkan media guna untuk memperjelas pada siswa mengenal pembelajaran, misalnya menyajikan bahan dalam bentuk visual berupa gambar-gambar yang berhubungan dengan materi pembelajaran.

c. Bahan ajar atau buku paket siswa yang kurang mencukupi sehingga situasi semacam ini guru dituntut untuk menyediakan kreasi guru yang sesuai dengan kemampuan siswa dalam bentuk media sesuai dengan materi pembelajaran guna tidak membosankan siswa dalam proses belajar mengajar.

\section{Media yang dikembangkan}

Siswa bekerja dalam kelompok dua atau tiga orang, setiap anggota tim membaca kreatif dengan sesuai teks yang telah disediakan, sedangkan tim kelompok lain mengamati dan memberi tanggapan, begitu juga sebaliknya dengan kelompok lain. 
Penggunaan media pembelajaran dalam proses belajar mengajar pada siswa digunakan pada situasi sebagai berukut :

a. Saat suasana siswa lagi bingung dalam memahami proses pembelajaran ini juga salah satu akibat dari kebosanan yang timbul oleh materi guru yang sifatnya menonton tanpa selingan berupa humor yang menyenangkan.

b. Pada waktu pembelajaran dibagian kegiatan inti agar siswa dapat mengenal langsung tentang materi pembelajaran yang mungkin kurang dipahami siswa, dalam situasi seperti ini guru harus berusaha dan bijaksana menampilkan media guna untuk memperjelas pada siswa mengenal pembelajaran, misalnya menyajikan bahan dalam bentuk visual berupa gambar-gambar yang berhubungan dengan materi pembelajaran.

c. Bahan ajar atau buku paket siswa yang kurang mencukupi sehingga situasi semacam ini guru dituntut untuk menyediakan kreasi guru yang sesuai dengan kemampuan siswa dalam bentuk media sesuai dengan materi pembelajaran guna tidak membosankan siswa dalam proses belajar mengajar.

d. Siswa bekerja dalam kelompok tiga atau empat orang, setiap anggota tim membaca kreatif dengan sesuai teks yang telah disediakan, sedangkan tim kelompok lain mengamati dan memberi tanggapan dari teks tersebut, begitu juga sebaliknya dengan kelompok lain.

\section{METODE PENELITIAN}

\section{Tempat dan Waktu Penelitian}

Penelitian dilaksanakan di SMP Negeri 3 Sampoiniet Kecamatan Sampoiniet Kabupaten Aceh Jaya. Lokasi SMP Negeri 3 Sampoiniet sangat strategis, karena terletak di tengah-tengah pemukiman penduduk, sehingga mudah dijangkau oleh para siswanya. Penelitian tindakan kelas ini dilaksanakan selama 3 (tiga) minggu atau 1 (satu) bulan, yaitu mulai dari tanggal 13 September sampai dengan 27 September 2018. Kegiatan penelitian ini meliputi persiapan, pelaksanaan, dan penyusunan laporan. Kegiatan persiapan meliputi observasi, identifikasi masalah, penentuan tindakan, Pengajuan judul, Pengajuan ijin penelitian, dan pengumpulan data penelitian.

\section{Subjek Penelitian}

Subyek penelitian ini adalah siswa kelas VIII SMP Negeri 3 Sampoiniet Kabupaten Aceh Jaya tahun pelajaran 2018/2019. Seluruh siswa kelas VIII SMP Negeri 3 Sampoiniet dijadikan subyek penelitian. Jumlah subyek dalam penelitian ini yaitu 18 orang siswa yang terdiri dari 2 siswa laki-laki dan 16 siswa perempuan.

Siswa kelas VIII SMP Negeri 3 Sampoiniet mayoritas berasal dari keluarga dengan katagori menengah ke bawah, oleh karena itu sebagian waktunya di rumah, sehingga mereka jarang melakukan latihan olahraga karena sibuk dengan kegiatan membantu orang tua dan sebagainya. Apalagi untuk materi latihan senam lantai dasar, mereka para siswa masih sangat asing, artinya mereka hanya akrab dengan olahraga permainan seperti sepak bola, sehingga materi senam latai seolah-olah dikesampingkan.

\section{Pengumpulan Data}

Data yang diperlukan dalam penelitian ini berupa hasil wawancara dengan subyek penelitian dan sumber data yaitu guru, dan pengumpulan catatan hasil pengamatan. Hasil pengamatan dikumpulkan melalui pengamatan, hasil tes siswa dan angket. Pemberian dan pengisian angket oleh siswa dilaksanakan pada pertemuan ke kedua (siklus terakhir), setelah tindakan selesai. 


\title{
Teknik Pengumpulan Data
}

Data yang diperoleh dengan cara sebagai berikut test dan observasi.

\author{
Alat Pengumpulan Data \\ a. Butir Soal Test \\ b. Lembar Instrumen aktivitas siswa \\ c. Lember Instrumen guru
}

\section{Uji Validitas Data}

Data yang sudah terkumpul merupakan modal awal yang sangat berharga dalam penelitian ini, dari data yang terkumpul akan dilakukan analisis yang selanjutnya dipakai sebagai bahan masukan untuk penarikan kesimpulan. Melihat begitu besarnya posisi data, maka keabsahan data yang terkumpul menjadi sangat vital.

Keabsahan data itu dikenal sebagai validitas data, sebagaimana dijelaskan Alwasilah (2008: 170) bahwa tantangan bagi segala jenis penelitian pada akhirnya adalah terwujudnya produksi ilmu pengetahuan yang valid, sahih, benar, dan beretika. Validitas data penelitian tindakan kelas ini diuji dengan menggunakan triangulasi, yaitu:

1. Hasil belajar permainan bola basket dianalisis dengan menggunakan triangulasi, yaitu dengan data yang diperoleh dari peneliti, observer, dan siswa.

2. Keaktifan siswa dianalisis dengan menggunakan data yang diperoleh dari peneliti, observer, dan siswa.

3. Aktifitas guru dianalisis dengan menggunakan data yang diperoleh dari peneliti, observer, dan siswa.

4. Penggunaan alat bantu yang aman dianalisis dengan menggunakan data yang diperoleh dari peneliti, observer, dan siswa.

5. Nilai hasil belajar sebelum tindakan divalidasi dengan triangulasi peneliti.

6. RPP, silabus, kurikulum divalidasi dengan triangulasi dokumen.

7. Emosi siswa divalidasi dengan triangulasi kartu ceria.

\section{Analisis Data}

Data yang dianalisis meliputi data kuantitatif (dengan menampilkan angka-angka sebagai ukuran prestasi), dan data kualitatif (dengan menampilkan angka sebagai perbandingan). Analisis data dilakukan secara deskriptif komparatif yang bertujuan untuk membandingkan kondisi sebelum dan sesudah diadakan tindakan perbaikan pembelajaran. Tahapan dalam tindakan menganalisis data meliputi reduksi data, penyajian data, dan penarikan kesimpulan.

\section{Prosedur Penelitian}

Menurut prosedur penelitian tindakan kelas, maka penelitian ini dilaksanakan dalam bentuk siklus yang terdiri dari empat tahap yaitu Perencanaan (plaining), tindakan (action), pengamatan (observing), dan refleksi (reflecting)..

\section{HASIL TINDAKAN DAN PEMBAHASAN Deskripsi Pratindakan}

Kegiatan pratindakan dilakukan sebelum pelaksanaan proses penelitian tindakan kelas berlangsung yang dimaksudkan untuk mengetahui keadaan sebenarnya tentang kondisi pembelajaran senam lantai. siswa kelas VIII SMP Negeri 3 Sampoiniet Kabupaten Aceh Jaya Tahun Pelajaran 2018/2019 yang berjumlah 18 siswa yang terdiri 
dari 2 siswa laki-laki dan 16 siswa perempuan. Hasil belajar yang diperoleh pada kegiatan pratindakan pembelajaran senam lantai masih sangat rendah.

Perhatian siswa tidak terfokus pada pembelajaran, terutama pada saat guru menyampaikan materi, hal itu disebabkan oleh karena guru belum menggunakan metode pembelajaran yang tepat dalam materi senam lantai.

Tabel Deskripsi Data Hasil Belajar Awal/Pratindakan

\begin{tabular}{|c|c|c|c|}
\hline No & Kriteria & Jumlah Anak & Prosentase \\
\hline 1. & Tuntas & 9 & $50 \%$ \\
\hline 2. & Belum tuntas & 9 & $50 \%$ \\
\hline & JUMLAH & 18 & $100 \%$ \\
\hline
\end{tabular}

Hasil penilaian pratindakan terhadap pembelajaran tentang senam lantai siswa masih rendah, hanya 9 siswa (50\%) yang telah mampu melakukan senam lantai. dengan benar. Melalui deskripsi data awal, masing-masing aspek menunjukkan kriteria keberhasilan pembelajaran yang kurang, maka disusun sebuah tindakan untuk meningkatkan hasil belajar senam lantai. pada siswa kelas VIII SMP Negeri 3 Sampoiniet dengan menggunakan alat bantu pembelajaran. Pelaksanaan tindakan dilakukan dengan 2 siklus, yaitu perencanaan, pelaksanaan tindakan, observasi, dan refleksi.

Tabel Instrumen observasi aktivitas siswa dalam PBM Pratindakan

\begin{tabular}{|c|l|c|c|c|c|}
\hline No & \multicolumn{1}{|c|}{ Nama Siswa } & $\begin{array}{c}\text { L/ } \\
\text { P }\end{array}$ & KKM & $\begin{array}{c}\text { Nilai } \\
\text { Pratin } \\
\text { dakan }\end{array}$ & $\begin{array}{c}\text { Keterangan } \\
\text { Tuntas/Tidak } \\
\text { Tuntas }\end{array}$ \\
\hline 1 & Ahmad Baizawi & L & 70 & $\mathbf{4 0}$ & Tidak Tuntas \\
\hline 2 & Asmaul Husna & P & 70 & $\mathbf{5 0}$ & Tidak Tuntas \\
\hline 3 & Cut Deli & P & 70 & 78 & Tuntas \\
\hline 4 & Erni Zakia & P & 70 & $\mathbf{6 7}$ & Tidak Tuntas \\
\hline 5 & Fatimahwati & P & 70 & 70 & Tuntas \\
\hline 6 & Hirma Paramita & P & 70 & $\mathbf{5 9}$ & Tidak Tuntas \\
\hline 7 & Indah Zarina & P & 70 & $\mathbf{6 0}$ & Tidak Tuntas \\
\hline 8 & Khatijah & P & 70 & $\mathbf{6 3}$ & Tidak Tuntas \\
\hline 9 & Nadiatun & P & 70 & 40 & Tidak Tuntas \\
\hline 10 & Putri Wifratul Aina & P & 70 & $\mathbf{5 0}$ & Tidak Tuntas \\
\hline 11 & Qurratulaini & P & 70 & 78 & Tuntas \\
\hline 12 & Siti Marhamah & P & 70 & $\mathbf{6 7}$ & Tidak Tuntas \\
\hline 13 & Tia Aprilia & P & 70 & 70 & Tuntas \\
\hline 14 & Tia Safitri & P & 70 & 80 & Tuntas \\
\hline 15 & Umul Aiman & P & 70 & 70 & Tuntas \\
\hline 16 & Yurna Laina & P & 70 & 78 & Tuntas \\
\hline 17 & Yusri & L & 70 & 70 & Tuntas \\
\hline 18 & Zahratu Jannah & P & 70 & 78 & Tuntas \\
\hline \multicolumn{2}{|l}{ Jumlah Rata-rata dan Katagori } & & $\mathbf{7 0}$ & $\mathbf{6 5}$ & Tidak \\
& & & & & Tuntas \\
\hline
\end{tabular}

Dimana pada lembaran observasi aktifitas belajar siswa terjadi perubahan hasil belajar siswa bisa dilihat dari grafik berikut ini : 
Tabel Grafik Hasil Tes Formatif Pratindakan

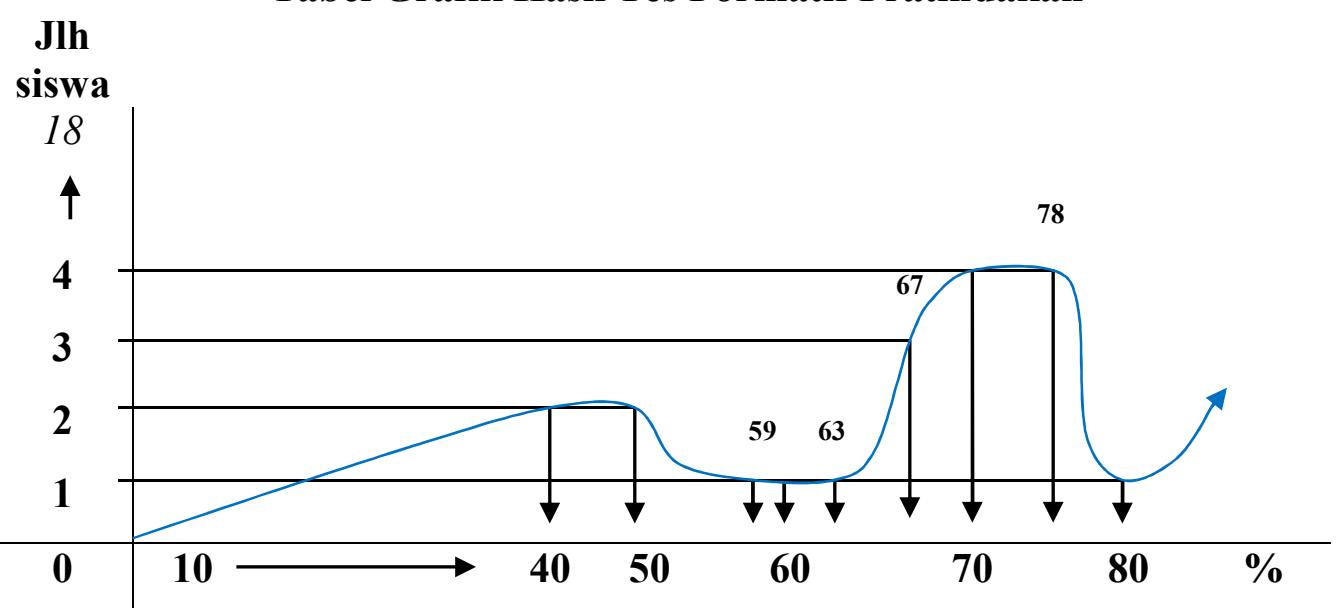

\section{Deskripsi Hasil Tindakan Tiap Siklus}

Siklus I

Pembelajaran latihan senam lantai pada siklus I menggunakan alat bantu pembelajaran.Siswa mengikuti pembelajaran dengan teknik dasar dalam senam lantai. dan dengan menggunakan metode demonstrasi.

Tabel Deskripsi Data Hasil Belajar Siklus I

\begin{tabular}{|c|c|c|c|}
\hline No & Kriteria & Jumlah Anak & Prosentase \\
\hline 1. & Tuntas & 15 & $83 \%$ \\
\hline 2. & Belum tuntas & 3 & $17 \%$ \\
\hline & Jumlah & 18 & $100 \%$ \\
\hline
\end{tabular}

Berdasarkan hasil deskripsi data siklus I, hasil senam lantai. melalui metode demontrasi siswa sebanyak 15 siswa (83\%) telah mencapai KKM dan sisanya 3 siswa (17\%) belum mencapai KKM.

Tabel Instrumen observasi aktivitas siswa dalam PBM Siklus I.

\begin{tabular}{|c|l|c|c|c|c|}
\hline No & \multicolumn{1}{|c|}{ Nama Siswa } & L/P & KKM & $\begin{array}{c}\text { Nilai } \\
\text { Siklus 1 }\end{array}$ & $\begin{array}{c}\text { Keterangan } \\
\text { Tuntas/Tidak } \\
\text { Tuntas }\end{array}$ \\
\hline 1 & Ahmad Baizawi & L & 70 & $\mathbf{6 0}$ & Tidak Tuntas \\
\hline 2 & Asmaul Husna & P & 70 & $\mathbf{6 8}$ & Tidak Tuntas \\
\hline 3 & Cut Deli & P & 70 & 78 & Tuntas \\
\hline 4 & Erni Zakia & P & 70 & 77 & Tuntas \\
\hline 5 & Fatimahwati & P & 70 & 80 & Tuntas \\
\hline 6 & Hirma Paramita & P & 70 & $\mathbf{6 9}$ & Tidak Tuntas \\
\hline 7 & Indah Zarina & P & 70 & 70 & Tuntas \\
\hline 8 & Khatijah & P & 70 & 73 & Tuntas \\
\hline 9 & Nadiatun & P & 70 & 78 & Tuntas \\
\hline 10 & Putri Wifratul Aina & P & 70 & 77 & Tuntas \\
\hline 11 & Qurratulaini & P & 70 & 80 & Tuntas \\
\hline 12 & Siti Marhamah & P & 70 & 70 & Tuntas \\
\hline 13 & Tia Aprilia & P & 70 & 75 & Tuntas \\
\hline 14 & Tia Safitri & P & 70 & 85 & Tuntas \\
\hline 15 & Umul Aiman & P & 70 & 75 & Tuntas \\
\hline 16 & Yurna Laina & P & 70 & 80 & Tuntas \\
\hline
\end{tabular}




\begin{tabular}{|l|l|c|c|c|c|}
\hline 17 & Yusri & $\mathrm{L}$ & 70 & 75 & Tuntas \\
\hline 18 & Zahratu Jannah & $\mathrm{P}$ & 70 & 80 & Tuntas \\
\hline \multicolumn{2}{|c|}{ Jumlah Rata-rata dan katagori } & $\mathbf{7 0}$ & $\mathbf{7 5}$ & Tuntas \\
\hline
\end{tabular}

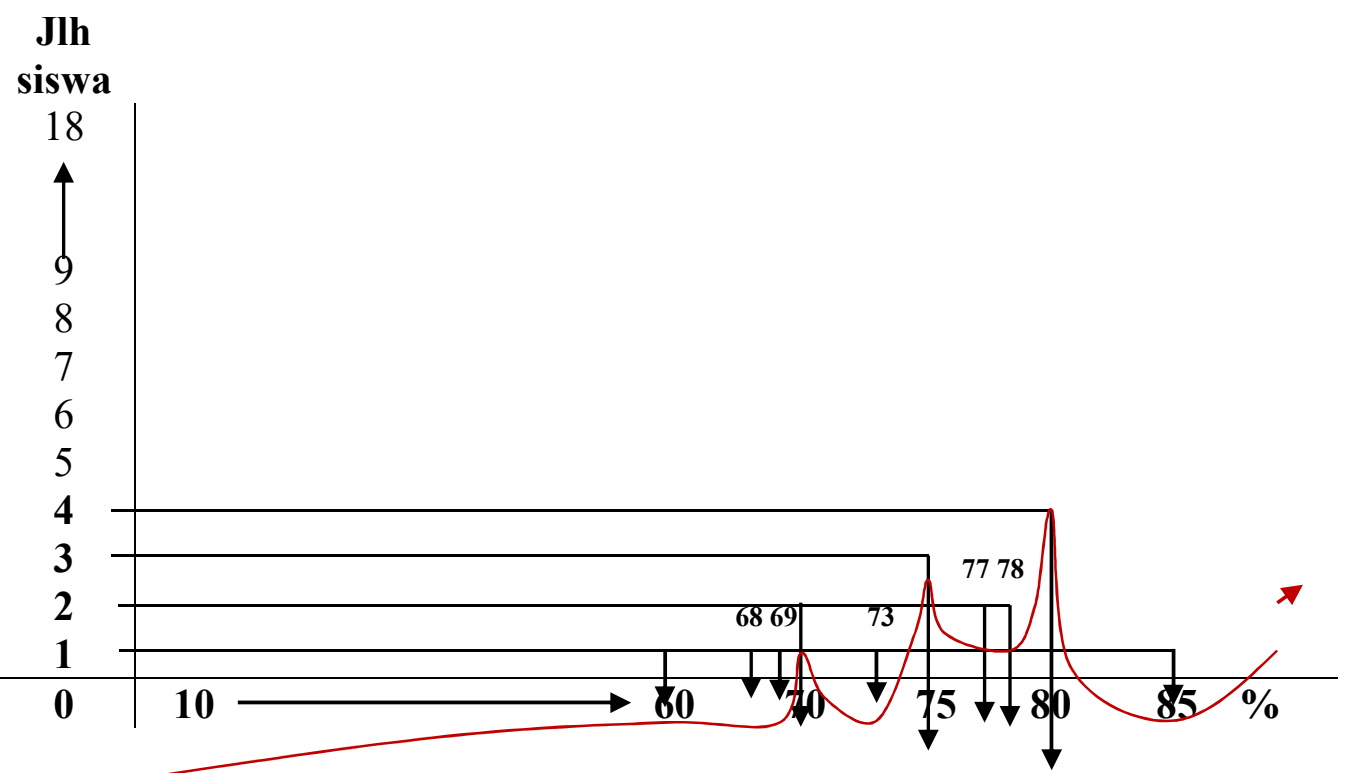

Dari hasil diatas sudah terlihat perubahan yang sangat berarti, ini dikarenakan guru sudah menggunakan media pembelajaran melalui metode demonstrasi.

\section{Siklus.II}

Pembelajaran sanam lantai pada siklus II merupakan tindakan lanjutan dari siklus I yang dirancang untuk memperbaiki hasil belajar dan kondisi pembelajaran siklus I. Pada siklus II ini siswa mengikuti pembelajaran permainan bola basket dengan menggunakan alat media yang sesuai.

Pengambilan data dilakukan selama pelaksanaan tindakan baik di siklus II. Deskripsi data yang diambil setelah tindakan siklus II dan disajikan dalam bentuk tabel sebagai berikut :

Tabel Deskripsi Data Hasil Belajar Siklus II

\begin{tabular}{|c|c|c|c|}
\hline No & Kriteria & Jumlah Anak & Prosentase \\
\hline 1. & Tuntas & 18 & $100 \%$ \\
\hline 2. & Belum tuntas & 0 & $0 \%$ \\
\hline & Jumlah & 18 & $100 \%$ \\
\hline
\end{tabular}

Berdasarkan hasil deskripsi data siklus II, hasil senam lantai melalui metode demonstrasi berjumlah 18 anak (100\%) telah mencapai KKM

Tabel Instrumen observasi aktivitas siswa dalam PBM Siklus II

\begin{tabular}{|c|l|c|c|c|c|}
\hline No & \multicolumn{1}{|c|}{ Nama Siswa } & $\begin{array}{c}\text { L/ } \\
\text { P }\end{array}$ & KKM & $\begin{array}{c}\text { Nilai } \\
\text { Siklus } \\
\text { II }\end{array}$ & $\begin{array}{c}\text { Keterangan } \\
\text { Tuntas/Tidak } \\
\text { Tuntas }\end{array}$ \\
\hline 1 & Ahmad Baizawi & L & 70 & 70 & Tuntas \\
\hline 2 & Asmaul Husna & P & 70 & 75 & Tuntas \\
\hline 3 & Cut Deli & P & 70 & 84 & Tuntas \\
\hline 4 & Erni Zakia & P & 70 & 80 & Tuntas \\
\hline 5 & Fatimahwati & P & 70 & 86 & Tuntas \\
\hline
\end{tabular}




\begin{tabular}{|c|c|c|c|c|c|}
\hline 6 & Hirma Paramita & $\mathrm{P}$ & 70 & 73 & Tuntas \\
\hline 7 & Indah Zarina & $\mathrm{P}$ & 70 & 75 & Tuntas \\
\hline 8 & Khatijah & $\mathrm{P}$ & 70 & 78 & Tuntas \\
\hline 9 & Nadiatun & $\mathrm{P}$ & 70 & 70 & Tuntas \\
\hline 10 & Putri Wifratul Aina & $\mathrm{P}$ & 70 & 75 & Tuntas \\
\hline 11 & Qurratulaini & $\mathrm{P}$ & 70 & 84 & Tuntas \\
\hline 12 & Siti Marhamah & $\mathrm{P}$ & 70 & 80 & Tuntas \\
\hline 13 & Tia Aprilia & $\mathrm{P}$ & 70 & 80 & Tuntas \\
\hline 14 & Tia Safitri & $\mathrm{P}$ & 70 & 95 & Tuntas \\
\hline 15 & Umul Aiman & $\mathrm{P}$ & 70 & 80 & Tuntas \\
\hline 16 & Yurna Laina & $\mathrm{P}$ & 70 & 85 & Tuntas \\
\hline 17 & Yusri & $\mathrm{L}$ & 70 & 80 & Tuntas \\
\hline 18 & Zahratu Jannah & $\mathrm{P}$ & 70 & 85 & Tuntas \\
\hline \multicolumn{3}{|c|}{ Jumlah Rata-rata dan Katagori } & 70 & 80 & Tuntas \\
\hline
\end{tabular}

Hasil belajar siklus II telah menunjukkan peningkatan sesuai dengan apa yang ditargetkan, yaitu seluruh siswa yang berjumlah 18 anak (100\%) telah mencapai nilai KKM. Berdasarkan hasil tersebut disimpulkan bahwa hasil belajar tentang senam lantai melalui penggunaan alat bantu ring target telah mencapai hasil yang memuaskan atau dengan kategori sangat baik.

Kelebihan dan keberhasilan tindakan siklus II akan dipertahankan dan berupaya untuk meningkatkan. Untuk memperbaiki kelemahan dan kekurangan tindakan siklus I, antisipasinya adalah peneliti memberikan motivasi yang lebih dan melakukan pendekatan personal kepada siswa, agar tetap berkonsentrasi agar tujuan dapat tercapai.

\section{Tabel Grafik Hasil Tes Formatif Siklus II}

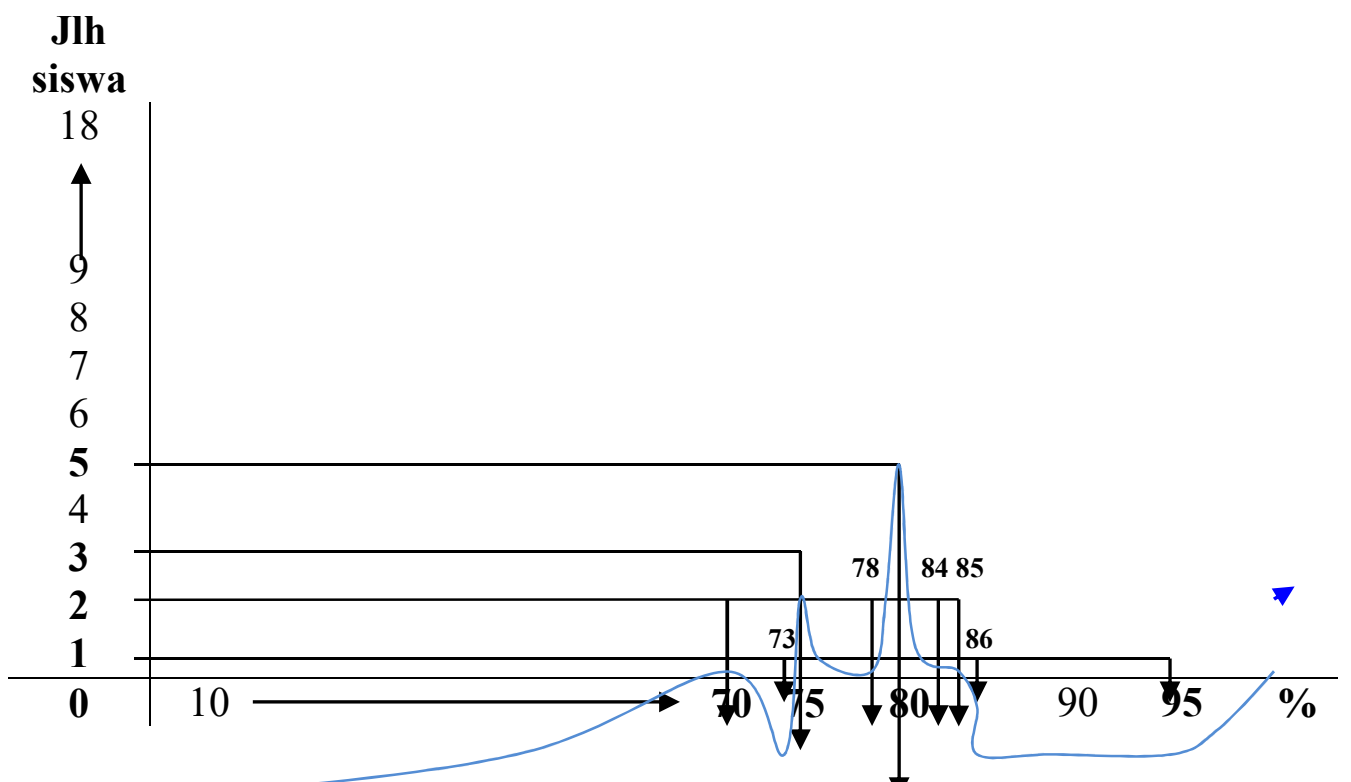

Sebagaimana yang dilakukan pada siklus I, dan pada siklus II telah dilakukan penjelasan yang mendalam disertai media pembelajaran yang sesuai dengan metode demonstrasi terhadap deskripsi data yang dipaparkan diatas. Dimana pada lembaran observasi hasil belajar siswa terjadi perubahan nilai yang sangat luar biasa.

\section{Perbandingan Hasil Tindakan Antarsiklus}

Pelaksanaan tindakan perbaikan pembelajaran senam lantai dari pratindakan, 
siklus I, dan siklus II melalui metode demonstrasi diketahui dari masing-masing tindakan telah mengalami peningkatan hasil belajar senam lantai siswa kelas VIII SMP Negeri 3 Sampoiniet Kecamatan .

Selama proses pembelajaran siswa terlihat aktif dan antusias, sehingga pembelajaran berlangsung kondusif, sehingga hasil belajar sesuai dengan yang telah ditargetkan. Perbandingan hasil yang diperoleh selama proses tindakan dijabarkan dalam bentuk table sebagai berikut:

Tabel Perbandingan Hasil Belajar Pratindakan, Siklus I, dan Siklus II

\begin{tabular}{|c|c|c|c|c|}
\hline No & Kriteria & Pratindakan & Siklus I & Siklus II \\
\hline 1. & Tuntas & $50 \%$ & $83 \%$ & $100 \%$ \\
\hline 2. & Belum tuntas & $50 \%$ & $17 \%$ & $0 \%$ \\
\hline \multicolumn{2}{|c|}{ JUMLAH } & $\mathbf{1 0 0 \%}$ & $\mathbf{1 0 0 \%}$ & $\mathbf{1 0 0 \%}$ \\
\hline
\end{tabular}

Data pada tabel diatas menunjukkan adanya peningkatan hasil belajar tiap siklusnya. Pada kegiatan pratindakan Persentase ketuntasan siswa baru mencapai 50\% saja, setelah dilakukan kegiatan siklus I hasil ketuntasan belajar siswa meningkat menjadi 83\%, kemudian pada kegiatan pembelajaran siklus II hingga seluruh siswa $(100 \%)$ telah tuntas belajar, ini menunjukkan bahwa penggunaan alat bantu berupa matras pada pembelajaran senam lantai dapat membantu meningkatkan keaktifan dan motivasi siswa sehingga hasil belajar meningkat dan mencapai tingkat ketuntasan yang diharapkan.

Di samping hasil belajar, fokus dan keaktifan siswa juga meningkat, siswa terfokus pada pembelajaran, seluruh siswa juga telah aktif mengikuti pembelajaran, mereka terlihat antusias mengikuti pembelajaran.

\section{Pembahasan}

Berdasarkan hasil penelitian terdapat perbedaan prestasi belajar siswa antara siswa yang menggunakan media pembelajaran dan metode demonstrasi di SMP Negeri 3 Sampoiniet menunjukkan bahwa rata-rata berbobot yang diperoleh dengan rumus :

$$
\begin{aligned}
& \sum F i X I \\
& \bar{X}=\frac{i=1}{\sum F i}
\end{aligned}
$$

Siklus I rata-rata $65 \%$

Siklus II rata-rata $75 \%$

Siklus III rata-rata $80 \%$

Peningkatan hasil belajar siswa dapat dilihat dari tabel-tabel yang telah disajikan, yaitu pada pratindakan, siswa yang telah mencapai nilai KKM, 9 anak (50\%) pada kegiatan pratindakan dan sisanya 9 anak belum mencapai nilai KKM. Pada siklus I siswa yang telah mencapai nilai KKM 15 anak (83\%) dan sisanya 3 anak belum mencapai nilai KKM.

Pada siklus II seluruh siswa yang berjumlah 18 anak (100\%) telah mencapai nilai KKM. Dari pratindakan dari kegiatan pratindakan $(50 \%)$ ke siklus I $(83 \%)$ dan siklus II $(100 \%)$ jika dibandingkan terlihat hasil belajar siswa mengalami kenaikan menjadi (50\%) dari siklus I ke siklus II juga terjadi peningkatan hingga $17 \%$. Sebagaimana yang dilakukan pada siklus I, pada dan pada siklus II telah dilakukan penjelasan yang mendalam disertai media pembelajaran yang sesuai dengan deskripsi data yang dipaparkan diatas. 
Nilai rata-rata klasikal sebanyak dari total siswa dalam satu kelas mendapat nilai tercapai pada kegiatan pratindakan, siklus I, dan II. Dari tabel di atas dapat digambarkan dalam diagram di bawah ini :

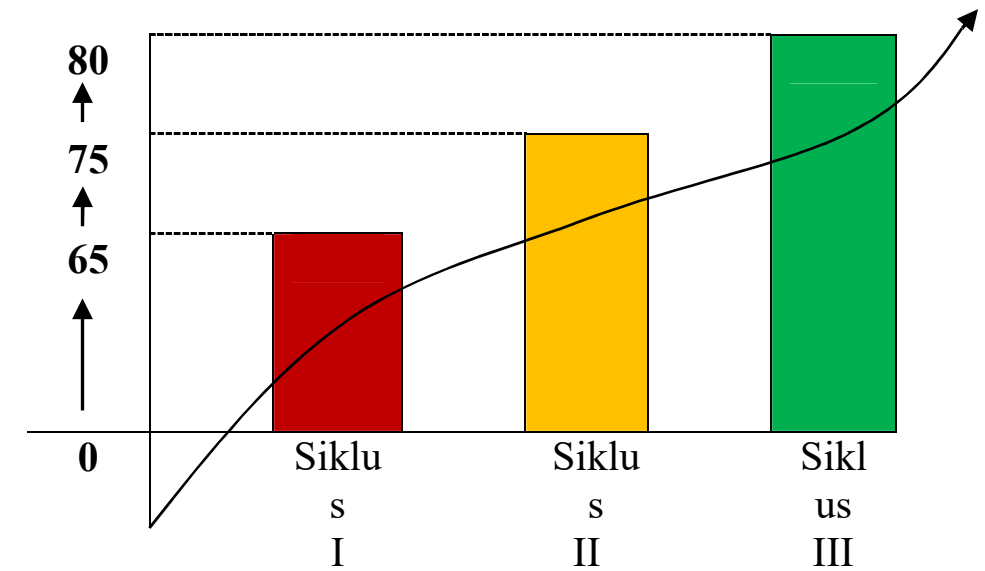

Tabel Perubahan nilai rata-rata klasikal belajar siswa

\section{Kesimpulan}

Kesimpulan penelitian ini adalah pembelajaran senam lantai melalui penggunaan alat bantu berupa matras dapat meningkatkan fokus dan keaktifan siswa serta suasana pembelajaran yang menyenangkan, sehingga pada akhirnya dapat meningkatkan hasil belajar siswa.

Penelitian ini berimplikasi bagi perkembangan pembelajaran pendidikan jasmani dan olahraga kesehatan di SMP Negeri 3 Sampoiniet. Guru pendidikan jasmani dan olahraga kesehatan dapat menerapkan pembelajaran senam lantai melalui penggunaan alat bantu yang sesuai dapat pula digunakan pada kegiatan lainnya, terutama pada cabang atletik, sehingga siswa merasa tertarik dengan pembelajaran yang menyenangkan sehingga tujuan akhirnya adalah dapat meningkatkan hasil belajar siswa.

\section{DAFTAR PUSTAKA}

Alwasilah, Chaedar. 2008. Pokoknya Kualitatif. Jakarta: Dunia Pustaka Jaya.

Balai Pustaka. 1995. Kamus Besar Bahasa Indonesia, Edisi Kedua. Jakarta: Depdikbud. Purwodarminto, 1976. Kamus besar bahasa Indonesia. Jakarta: Balai Pustaka Roestiyah. 2001. Strategi Belajar Mengajar. Jakarta: Rineka Cipta

Susilo, Herawati dkk, 2008. Penelitian Tindakan Kelas, Malang, Bayumedia Publising.

Usman, Moh User, 1991 . Menjadi Guru Profersional, Bandung, PT Remaja Rosdakarya. 